\title{
GCU
}

Glasgow Caledonian

University

University for the Common Good

\section{The pious dissidence in Turkey: contesting religious neoliberal governmentality under the AKP}

Korkut, Umut; Sarfati, Yusuf

Published in:

Politics

DOI:

$10.1177 / 0263395719896285$

Publication date:

2020

Document Version

Author accepted manuscript

Link to publication in ResearchOnline

Citation for published version (Harvard):

Korkut, U \& Sarfati, Y 2020, 'The pious dissidence in Turkey: contesting religious neoliberal governmentality under the AKP', Politics, vol. 40, no. 4, pp. 413-427. https://doi.org/10.1177/0263395719896285

\section{General rights}

Copyright and moral rights for the publications made accessible in the public portal are retained by the authors and/or other copyright owners and it is a condition of accessing publications that users recognise and abide by the legal requirements associated with these rights.

Take down policy

If you believe that this document breaches copyright please view our takedown policy at https://edshare.gcu.ac.uk/id/eprint/5179 for details of how to contact us. 


\section{The Pious Dissidence in Turkey}

\section{Contesting religious neoliberal governmentality under the AKP}

\section{Introduction}

There is a growing literature on the evolving relationship between neoliberal projects and religion in various contexts (Tugal, 2009; Bugra and Savaskan, 2014; Martikainen and Gauthier, 2016). Turkey under successive Justice and Development Party (Adalet ve Kalkinma Partisi, AKP) governments offers an ideal opportunity to examine how religion, authoritarianism, and the economic logic of neoliberalism could interrelate. Since its inception, AKP has promoted an ideological profile that combines neoliberalism and Islam (Atasoy, 2009). Particularly in its third term in office, AKP's brand of Islamism became increasingly authoritarian while centralized religion was used as a tool for social engineering to co-opt people into neoliberalism (Korkut and Eslen-Ziya, 2017). We are interested in how this process triggered contestation, particularly that of the "pious" Muslims' including their deliberations on adaptation and resilience to the AKP's conservative neoliberalism. Their contestation unfolds as follows: first, the pious problematize the frames of reference that the political system rests upon; second, they interrogate this frame and present its inconsistencies; third, they produce their own discourse presenting the inconsistencies among the religious, political and economic pillars of the political system. What matters to us is not the electoral strength of this contestation, but its capacity to question the system from within. This presents a rupture in the "conduct of conduct" foreseen by neoliberal governmentality. Therefore, we demonstrate how the neoliberalised subject contests the social context of governmentality questioning its very techniques. We call this contesting neoliberal governmentality. Empirically, we depict the formulation of "pious dissidence" in Turkey, follow their deliberations on Islamic identity 
facing corruption, injustice, and oppression in modern Turkish politics, and finally present the contestation of religiously informed neoliberal governmentality by the very constituency, i.e., the pious, that the AKP purports to represent.

\section{The Argument}

In Turkey, the Kemalist state has historically used religion as a political tool to organize the polity and the public along its own ideological tenets. This meant embracing a reformed Islam, marginalizing Islamism in the sociopolitical realm, and creating modern, secular citizens. Recently, AKP-led governments sought to organize religious roles and identities to encourage human capital to serve neoliberalism, and appealed to a state-controlled religion in order to entrench its domination (Korkut and Eslen-Ziya 2017). This has forged a highly economized idea of the common good, suggesting social identities and roles in confluence with the neoliberal goals of the political authority. We are interested in how the pious dissidents react towards resilience and adaptability themes embedded in the AKP's political narrative. This shows how pious Muslims position themselves between the politico-religious authority and their piety, and therefore, the limits of AKP's political dominance over its very constituency. To elaborate on these conceptual claims, we primarily refer to interviews with Labor and Justice Platform (Emek ve Adalet Platformu, LJP) members. We delineate their justice-oriented, egalitarian, and pluralist orientation of Islam, and depict their dialogues with power - embodied in AKP's domination of Islamic discourse in Turkey. LJP is not a mass movement, but its discourse and practices are significant in demonstrating that the Islamic public sphere in Turkey is not univocal. LJP members promote alternative conceptions of morality, justice, authority, citizenship, and economic relations from an Islamic perspective at a 
time when most of the Islamic civil society is coopted by the AKP. The group primarily focuses on labor and urban issues in order to highlight injustices faced by subcontractor workers, the homeless, low-income residents facing gentrification in their neighborhoods and other underprivileged populations. Their actions demonstrate that there remain pockets of resistance in the Islamic public sphere that consciously challenge AKP's neoliberal Islamist authoritarianism.

The LJP is not the only group within the larger Islamic public sphere that poses a challenge to AKP's hegemony. For instance, Reçel Blog, an Islamic feminist online blog, provides a platform to pious women's voices in the intersection of gender and religious identities. Alternative conceptions of gender relations within the Muslim community are widely discussed and circulated in this forum. Similarly, the Muslim Initiative against Violence against Women (Kadına Karşı Şiddete Karşı Müslümanlar Insiyatifi) is a women's rights group close to the LJP that highlights violence against women within the Muslim community through various activities, including writing its own Friday sermon (hutbe) against violence against women and circulating them in mosques in Fatih and Üsküdar. The Right Initiative (Hak Insiyatifi) is an Islamic human rights advocacy group that documents abuses by the AKP governments, particularly in Turkey's Kurdish regions. These groups as well as others work in tandem with the LJP and constitute within the larger Islamic public sphere a counter-public, in which feminist, liberatory, egalitarian and pluralist interpretations of Islam are created in sharp contrast to AKP's authoritarian religious neoliberal governmentality. Therefore, our focus on LJP's activities, as a case of pious dissidence, highlights the multivocality of Turkey's Islamic public sphere and goes beyond studies that solely focus on the AKP to understand Islam in 
Turkey. This is significant in countering Orientalist accounts in the West that represent Islamic activism in Turkey and elsewhere as homogenous and authoritarian.

These pious voices oppose the AKP, which has not only used religion to promote obedience to political authority, but also pacified and contained identities in highly economized terms (Çalışkan and Callon, 2009) to serve a politically defined common good (Korkut and Eslen-Ziya, 2017). Erdoğan himself notoriously foregrounds such concepts as kader (fate), kısmet (destiny), şükür (thankfulness), sabır (steadfastness) in his speeches in order to shirt the responsibility to a divine being when his government fails to deliver. Following a mining disaster in Zonguldak where 30 miners died, Erdoğan stated that "[accidents] are the fate for the mining occupation and my brothers who join this occupation, when they assume their jobs are aware that these kinds of things can happen" (Sabah 2010). It is typical for AKP politicians to ask steadiness in the aftermath of major disasters, such as train accidents, floods, or terror attacks in an attempt to conceal their responsibilities. We take the AKP's efforts to shift responsibility to divinity and attempts to cultivate public interpretations of avoidable disasters using references imbued with religious themes as a sign of the 'conduct of conduct' sought by neoliberal governmentality with religious undertones. Therefore, we examine politicized religion supporting political authority as the embodiment of a politico-religious apparatus in the Foucauldian sense (Campbell and Sitze, 2013), and its operation as a case of the 'conduct of conduct' aiming to shape, guide or affect some person or persons' conduct of their own affairs (Gordon, 1991: 2). Yet, in contrast to the Foucauldian framework, we argue that this conduct of conduct under the monopolized and centralized religious discourse would not pacify dissent, but unleash it amongst the pious. 
Thus, we present pious dissidence in two senses: first, the elaborations of LJP members on being Muslim and, second, their counter definitions and representations of roles and identities. We show their contestation of the conduct of conduct by examining their contestation of the government politicians' religious interpretations of events that are otherwise avoidable. In particular, we outline three areas of dissent voiced by the LJP members towards the AKP. First, the group expresses a sharp criticism of market Islam or any efforts to mix religion and neoliberal economics. In their critique of market Islam, group members emphasize profound injustices that stem from neoliberal economic order and focus on Islamic principles of equality, brotherhood and labor rights. Second, LJP members challenge political Islam. Although some members of the LJP come from Islamist circles and use religion as a reference point to address sociopolitical challenges, the LJP does not designate itself as merely an Islamist formation. In their critique of Islamism, group members embrace a multi-vocal view of Islamic teachings and claim that no group should be able to speak in the name of Islam. Rather they emphasize a multiplicity of interpretations of Islam and the need to foreground the liberatory, egalitarian and justice-based aspects of the religion without adhering to Islam as an ideology or qualifying their work as a specifically Islamic cause. This position bears some similarities to post-Islamism, a term Asef Bayat (2005:5) defines as the metamorphosis of Islamism and "the birth, out of the Islamist experience, a qualitatively different discourse and politics." Lastly, the LJP expresses dissent against state-led Islam. Activists claim that the AKP's control of the state apparatus, its attempts to circulate a religious nationalist ideology through state institutions and its increasingly authoritarian politics corrupt Islam and adversely affect the perceptions of Islamic identity in Turkey. 


\section{Methods}

The LJP is a social-justice-oriented grassroots organization, formed in January of 2011 by bringing together young activists from Islamist and leftist circles. Its membership is almost evenly divided between university students and workers. Unlike conventional hierarchical movements, the meetings of the LJP are horizontally organized, where members have equal access to decision-making. In that regard there are no formal leaders in the movement, although some members are more active than others. We followed a qualitative approach, and conducted 11 open-ended interviews with members following snowball sampling. These interviews posed open-ended questions about participant's involvement with the LJP, the main issues they work on, the way they interpret critical political events and situate the group's position vis-à-vis other societal actors. The interviews were conducted in personal offices or public places and lasted between 45 minutes and two hours. Those interviewed were evenly divided between an older generation of members who were in their late $30 \mathrm{~s}$ and $40 \mathrm{~s}$ and younger activists in their 20s. Only two of the interviewees were women, although women constitute about 40 percent of the organization's membership. Hence, gender balance was a limitation.

In addition, we analyzed seven interviews group members gave to media. To supplement the interview data, we examined the organization's principles published in 2011 and revised in 2014, and various articles written by group members. We used critical discourse analysis (CDA) to locate recurring themes in the interview transcripts and group members' writings. Using CDA, we aim to make "explicit the implicit relationship between discourse, power, and ideology, challenging surface meanings" (van Dijk 1997: 11; Wodak 2011: 304). Through systematic analysis of LJP's discursive practices we identified three main themes 
commonly used by group members to challenge AKP's hegemonic political position in Turkey's Islamic public sphere.

\section{Moral politics, market Islam, governmentalities and regulation}

This article explores contestation to neoliberal governmentality with Islamic characteristics. Neoliberal governmentality is not a mere hegemonic state discourse, but rather an elaboration of subtler forms of state power (Allen, 2003; Larner, 2003: 512). A state-led moral politics to affect the conduct of being a proper Muslim is its goal for its subjects to subsequently perform their politically-condoned roles and identities. We focus on a rationality of governance that produces new kinds of political subjects where the border between the social and the economic has disappeared under the domination of a market rationality affecting all institutions and social practices (Oksala, 2013: 34). Hereby, we trace how moral politics becomes aligned with neoliberalism. Rose (1999: 176 in Hart, 2004: 92) argued that "rather than less government, neoliberalism represents a new modality of government predicated on interventions to create the organizational and subjective conditions for entrepreneurship inciting individuals to become entrepreneurs of themselves". In addition, there has been a process of 'responsibilization' aligned with these interventions and deployed to encourage and harness

self-management among women and men that are the subjects of neoliberal modalities of government. Reflecting on Korkut and Eslen-Ziya (2017), we argue that these modalities represent politically and religiously condoned compartmentalized roles within families, neighborhoods, market spaces, and wider socio-economic environments. They also inform respective production roles allocated to women and men, urging them to remain meek and not become a burden on the system. 
We examine kader (fate), klsmet (destinty), şükür (thankfulness), sabır (steadfastness) as terms that are embedded in the Islamist political narrative and effect how one should lead their own conduct within a neo-liberal market economy. These terms enforce a rationality of an individualized responsibility, and thereafter lay the basis of resilience and adaptability techniques of the political authority. Hence, even if the state "steps back" and encourages the free conduct of individuals, and open up individual initiative as a premise of neoliberal economics, using Islamic references to self-awareness, reflexivity and responsibility, it enforces resilience. The resilience idea implies an element of self-transformation and virtuous acts to express a sense of a proper Muslimhood. It is designed to create a form of effective selfmanagement by making 'people better from inside'. Eventually, this resilience encourages the idea of an active citizenship whereby people take responsibility for their own social and economic well-being (Joseph, 2013: 42).

Foucault suggested that the conduct of conduct focuses on the internal capacities of individuals and accompanies a form of societal governance involving a shift away from the state provision of the means of security (2008 in Chandler, 2013: 218). In a way, by circulating religiously informed conduct of conduct, the politicians aim to boost the coping capacities of citizens to adapt to their difficulties and remain meek. The agency of security, thereby, shifts from state to society and to the individual. This means that governing operates indirectly when the resilience discourse seeks to boost the mental or subjective capacities of their objects to respond to various crises (Chandler, 2013: 211). In making resilience a matter of the 'everyday', an exceptional event becomes subsumed into the life process itself (Chandler, 2013: 215). Ultimately, the resilient subject is never conceived as passive or as lacking agency, but only as an active agent capable of achieving self-transformation (Chandler, 
2012: 217). Thereafter, resilience urges its subject to turn from a concern with the outside world to a concern with its own subjectivity, adaptability, reflexive understanding, risk assessments, and responsible decision making (Joseph, 2013: 40). This introduces the subject as homo œconomicus, that is, "the person who accepts reality [...], appears as someone manageable, someone who responds systematically to systematic modifications artificially introduced into the environment" (Foucault, 1979: 270 ed. Senellart, 2004 trans Burchell, 2008). This is someone who is eminently governable and a correlate of governmentality (Foucault, 1979: 270-271 ed. Senellart, 2004 trans Burchell, 2008).

While resilience becomes a tool to co-opt the public as subjects to neoliberal paradigms, it also seeks to trap dissidence within the system. Yet, we argue that this does not mean that the subjects would submit to the aims of the political authority without contestation. Considering the complexities that the subjects of discourse face in their worldly existence, our expectation here is to witness a deliberative process whereby they reflect on the identity and role patterns, and profess and ascribe to hybrid multi-vocal configurations of these patterns rather than following unified and coherent, even political, formulations (Larner, 2005: 10). Thereby, we propose how a space for contestation emerges within governmentality while governmentality remains a conjunctural enterprise that engenders its own mode of resistance (Hart, 2004). How does this happen? Not only for pious dissidence, but also for feminist resistance (Fraser and Butler, 1997 in Oksala, 2013), a Foucauldian approach to neoliberalism exposes the political constitution of the economic domain itself for critical scrutiny. Resistance to neoliberal governmentality means posing difficult philosophical questions such as: what is the epistemological status of economic truths? (Oksala, 2013) Read (2009: 34) comments that "any criticism of neoliberalism as governmentality must not focus on its errors, but on its 
particular production of truth". Oksala (2013: 40) argues that any analysis of power relations must recognize how power has to be understood as constituting the subjects themselves..

Yet, the contestation of and dissidence to neoliberal governmentality is an understudied area. A keyword search for "contestation" and "dissidence" in Foucault Studies journal delivers only a few results. Foucault places significant emphasis on the neoliberal figure of homo œconomicus as the eminently governable subject, as the mode of subjectivity par excellence for liberal/neo-liberal rationality of government, and for the organization of conduct of conduct. Hence, in his view of governmentality there are only entrepreneurs of the self, engaged in self-interested conduct as personal investment (Dilts, 2011: 136, 138). How to organize the conduct of these conducts requires techniques, practices, and a way of knowing that deals with responsive subjects (Dilts, 2011: 139). Yet, the governmentality thesis appears to make little room for "responsibilized individuals, whose affective selves constitute a key site for the exercise of governmental power" (E. Campbell, 2010: 36).

The activism within the LJP, however, shows how the techniques and practices to inform affective selves of political subjects fail, despite the dominant political narrative. To portray how this process unfolds, we follow the reactions from LJP to terms such as kader (fate), klsmet (destinty), şükür (thankfulness), sabır (steadfastness) - the very terms that compose the religiously informed political narrative. Rather than guiding pious group members, these terms trigger contestation. Our approach differs from the existing and limited research in the field of contestation of neoliberal governmentality. Wendy Brown associates contestation with opting out rather than addressing political problems (Brown, 2005: 43). Elaine Campbell (2010: 39) states that resistance is configured as a matter of self-reflexive choice or personal motivation to opt out of, ignore or dissociate from particular technologies 
and practices. Tie (2004 in Elaine Campbell, 2010: 40) argues that the possibilities for resistive action will always emerge accidentally rather than through a reflexive and critical process of self-realization. Akçalı, Yanık, and Hung (2015: 21) argue that neoliberal governmentality techniques, at least the way that Foucault has formulated them in his Birth of Biopolitics (2008), fail when there is no liberal capitalist base on which policymakers might draw upon in order to encourage the self-regulation of populations.

As we will present below, there is no opting out but instead continuous reflexive deliberation on the techniques of neoliberal governmentality. A discussion on to what extent the operation of neo-liberal governmentality depends on the type of political system is also timely. Governmentality studies have tended to focus preponderantly on "successful" cases rather than cases where governmentalization face obstacles (Merlingen, 2008 in Vrasti, 2013: 55). It is true that developed liberal economies can be governmentalized much easier (Joseph, 2010: 239). Yet, neoliberal governmentality is also contested in Turkey, despite its having a liberal capitalist base alongside an increasingly authoritarian political system. Our article, to this extent, presents two contributions to the field: (1) how contestation to neoliberal governmentality emerges in economically liberal but politically authoritarian contexts and (2) how both the governizer and the contester use similar terms to recruit "affective selves" (E. Campbell 2010: 40). The contester's resistance to the governizer's techniques of resilience and adaptability forms the limits of governmentality. Below, while we follow how the pious dissidence contests neoliberalism and its techniques of governmentalization, we show how they propose their claim to truth with a moral essence and encroach into the field of power that the AKP-led Islamic politics has purported to monopolize in Turkey. 


\section{Critiquing Market Islam}

The LJP is critical to AKP's neoliberal governmentality on various levels. Discursively, group members criticize global capitalist structures, the government's neoliberal policies, and the discursive control mechanisms that they identify with such terms as kader and klsmet. At the macro-economic level, group members engage in a fierce critique of global capitalism and describe it as the source of societal oppression:

Labor and Justice Platform sees capitalism as the source of oppression, exploitation, corruption and extravagance. At the origin of capitalism, there is oppression, evil, shame and immorality. [The movement] is neither circumspect nor hesitant to attack capitalism. It does not see this as being leftist or modernist, nor does it consider this [qualify capitalism as] a threat to the creed of Sunni Islam (ehl-i sünnet). It concentrates on social justice in its struggle against capitalism. In other words, its concern is with fair production, and sharing, and showing solidarity with the dispossessed, being content, and not wasting. [We take a position] against those arrogant that hoard gold and silver and circulate money and commodity among themselves (Buyukcoskun 2013).

The group members do not only see global capitalism as the main source of most injustices, but also describe the AKP with its neoliberal economic agenda as its foremost bearer in contemporary Turkey. As one activist points out:

Muslims, Islamists constructed their politics by focusing to change the government. Looking at AKP, what we see is that justice cannot be instituted by changing who occupies the government. And we look at the policies by this government such as its economic policies $[\ldots]$ we see that they produce oppression through different means. At the basis of this lies the issue of labor. When we look at [the government's] development policies, its employment policies, and how the resources of this land are used and distributed - and having noted the verse "there is nothing to man, but his labor" is so clear - we could see that distribution and allocation could create serious injustices, oppression. (Interview with Mustafa Emin Büyükcoşkun in Marje 62. Bölüm [Episode 62], IMCTV 2013)

The systemic injustices that occur under the AKP affect certain vulnerable populations particularly harshly. The LJP engages in local political actions that support the rights of these vulnerable populations. As one LJP member mentions: "We deal with workers and 
subcontractor workers issue. No government has increased [the number of] subcontractor workers as much as the AKP government has done" (Interview with Suat Yalçın, 5 June 2017). As a response to this, the LJP played an active role in the organization of "Subcontractor Workers Association" (Taşeron İşçileri Yardımlaşma ve Dayanışma Derneği, Taş-işs-der), which advocates for the job security and better workplace conditions for subcontractor workers. LJP members also participated in protests organized by subcontractor workers working in various municipalities (Koca 2014, p. 307). The LJP endorsed Cemal Bilgin, a health worker fired from his job in Istanbul University's hospital, who held protests every Friday in front of his workplace. One of the founders of the LJP, Zeki Kılıçaslan, explains the rationale for LJP's focus on subcontractor workers' rights: "Because [subcontractor workers] work under slavery conditions, [they] are the most victimized and oppressed group since they lack protection even by unions and workers' organizations" (Interview with Zeki Kilıçaslan, cf. Koca, 2014: p. 306). In addition, the group periodically highlights the victims of work accidents circulating annually "worker murders almanacs" and participating monthly in ‘conscience and justice watch' demanding accountability for workplace injuries and legislation with tighter safety measures for workers.

LJP's criticism of AKP's unabashed neoliberal policies became more visible during the Gezi Park protests and the Soma mining disaster where 301 miners died in 2014. During the Gezi Park Protests, the LJP brought together various influential Islamist intellectuals under the auspices of Mazlum Der - a reputable Islamic human rights organization - and issued a press statement accusing the AKP government of causing urban grievances and mistreating the protesters:

With its harsh arrogant face and scornful police brutality, the state tried to evict people, who were trying to protect those trees, under which so far only the destitute 
survived. [...] A political language that frames everything with reference to power and affluence, and sacralizes political power and economic development is not a language that reflects the morality of Muslims (Taksim Gezi Eylemleri Hakkında Açılama 2013).

This statement, which reflected LJP's main critique of AKP's attempts to combine Islam and neoliberalism, on the one hand, and AKP's embedding religion in state authority, on the other, encountered a significant backlash from the government, given its highly publicized Islamic credentials. This egalitarian Islamic critique exposed a potential rift in the cross-class alliance the AKP formed between Muslim middle classes and the urban poor. While the LJP harbors the potential to attract urban poor and dissuade them from supporting AKP's neoliberal project, this potential is far from being actualized given AKP's success in galvanizing support among different segments of Muslims. One group member explains the micro-mechanisms of this support as follows.

There are working class people around me, or women who go and clean houses, these are people I know. When I speak to them, they always say: "I am grateful to this," (buna da şükür) and one way or other they have the "patience (sabır)" thing, though they see that there is a problem. I would call this backward, but really I now see it this way. Now the mission of religion turned into something that is hollow to sedate people (Interview with Büşra ${ }^{1}, 19$ June 2017).

This observation eloquently reveals the discursive role the religious discourse plays in attracting lower class Muslims to AKP's brand. The thought that one needs to be grateful even though one does not earn much or the belief that with patience one will overcome one's economic woes reflect the resilience and adaptability narratives that AKP has embedded in its political discourse.

\footnotetext{
${ }^{1}$ The names of the interviewees are pseudonyms unless the first and last name of the interviewee is provided. In the latter case, these are the interviewee's real name, because the interviewee consented for their identity to be disclosed.
} 
Another narrative that bolsters the resiliency of AKP's religious neoliberal governmentality is kader or fate. The neoliberal economic system in Turkey has damaged worker safety extensively. In the first eleven months of 2018, 1797 workers died while at work, and during the AKP governments in 2002-2018, 1693 workers died at work only in the mining sector (Bianet 2018). It is common for AKP politicians to frame these worker deaths as fate, thereby absolving the government and employers from any responsibility. The LJP opposes this frame, and argues that most of these deaths could be preventable but first need to be called “worker murders." Mustafa Emin Buyukcoskun (2013), a group member, articulates how the AKP uses the fate narrative as a mechanism to legitimize its neoliberal rule:

After each mining accident there is a word that politicians, those who bear the primary responsibility, and employers always resort to: "Fate!" Insomuch as calling these deaths as accidents, explaining their occurrence as an act of fate, is deceptively "meaningful", considering that the existing system of politics and economics [in Turkey] still has claims of being secular. To process consent in this manner, to convince the workers and the public to believe in the responsiveness of the system only with this sort of language present clues pertinent to how Islamist codes [of action/behavior] operate in effect to politics in our lands as well their circulation and respective use

Buyukcoskun asserts that the AKP elites use Islamic idioms to assure the public's compliance with the neoliberal order, which defines every aspect of life in an otherworldly cost-benefit logic. This emerges as a usurpation of the fate narrative to manufacture the consent of the masses. While criticizing the AKP, Buyukcoskun also develops an alternative framing of fate to challenge the AKP discursively. He asserts that in Islam there are two different types of will, both of which explain life and death. The first is the absolute will of God over the universe and God's creatures (külli irade), while the second is the personal will (cüzzi irade), which refers to the control of God's creatures or believers over their own actions (ibid.) Buyukcoskun argues 
that the lack of worker safety measures leading to worker deaths would fall under the scope of personal will, not the absolute will of God:

Those who are liable for the safety of life and property of the worker are accountable not only to the worker but also to God in case of their death. [Their assumptions of] Accident, fate, in other words God's absolute will cannot dismiss their accountability; in contrast, it requires the self-accountability of the subject of God and their personal will (ibid.)

Our elaboration on thankfulness, patience and fate narratives are central to the resilience and adaptability framework that we foreground in this article. LJP members clearly understand how the AKP usurps certain concepts from folk Islam to seek pious citizens' compliance with neoliberal governmentality. Concepts, such as gratefulness, patience, or fate, are utilized to shift the responsibility from economic and political actors, such as the state and the corporations, to citizens themselves. Therefore, citizens that internalize these concepts take it upon themselves to cope with the death of a family member in the workplace, unemployment or underemployment, rather than holding the government responsible. This becomes particularly significant to the conduct of conduct, an essential aspect of neoliberal governmentality.

\section{Critiquing Political Islam}

As its name suggests the members of the "Labor and Justice" deliberately define their organization as a platform, where different ideas are exchanged and deliberated. Based on this definition it would be inaccurate to attribute an ideology to the group, and this lack of ideology makes it hard to situate the group's identity in established categories. Despite this lack of ideology, the group members coalesce around certain political principles. Values, such as right to labor, human dignity, social justice, anti-elitism, horizontal organization, localism, and antivanguardism are prioritized by the group. Based on these principles, LJP aims to create social 
justice by embracing local and Muslim values without any explicit reference to "Islam" in its foundational document. Turkish religious intellectuals, who emphasized egalitarian aspects of Islam, such as İhsan Eliaçık and Hayri Kırbaşoğlu, and international scholars, such as Hamid Dabashi and Farid Esack, who wrote on the liberatory potential of Islam, are read by the group members and provide inspiration for their work.

LJP's motto is "against serving the servant and exploitation" (kula kulluğa ve sömürüye karşı). The word choice of this motto shows how the LJP seeks to forge a synthesis between Islam and the left in Turkey by using an Islamic term (i.e., being a servant to God) in conjunction with exploitation - a word from leftist terminology. While bringing Islamists and leftists under one umbrella has been a goal of the LJP in its heydays, most members we interviewed were hesitant to define the LJP as "Islamic Left." After claiming that their organization cannot be defined as "Islamic Left," Büşra explained her reasoning:

[LJP's] relationship with both Islam and the left is out of the ordinary. Perhaps, [it is] the attempt to create a new language. Actually, it is an effort to explain to a religious person, who accepts the labor and urban issues that we experience in the context of Istanbul with patience by calling them destiny, klsmet, fate, that these occur due to a number of rational and class-based causes. In contrast, [the LJP] tries to make its cause by transcending the left's overtly positivist language that denies the folk culture (Interview with Büşra, 19 June 2017).

The attempt to create a new language of politics and the hesitance to adopt an ideological identity for the LJP is a conscious decision. Thus, the group's Muslim identity is not related to an explicit ideology but rather an embrace of certain values, such as helping marginalized members of society, resisting ethnic oppression, or supporting workers' rights, which can be deduced from both a pluralistic and egalitarian interpretation of Islam and other secular worldviews. The following conversation with one of the activists is informative in situating the group's position vis-à-vis Islamism: 
As Labor and Justice Platform, we are a group that recognizes Islamism's theoretical potential for liberation. We are not Islamists, but Islamism does not have to be in AK Party's or ISIS's or Fethullah Gulen's monopoly. A liberatory, pro-freedom and democratic vein is probably possible in Islamism [laughs]. In the past we said it is possible. Now we say it is probably possible [Interview with Akif June 2017].

While accepting the emancipatory potential of Islamism as an ideology and refusing to equate Islamism with the dominant Islamist political projects that are corrupt or violent, Akif claims that as a group they do not adopt the term Islamism. He continues to explain why this is the case:

Of course we are Muslims, [we are] pious, our work follows a Muslim point of view, (Müslümanca birşey yapıyoruz) and we will continue to do it. When you say that we do it for Islam, when you turn Islam to a flag, when you say we are doing this to elevate Islam, then you are on an off-side position. Therefore, [instead] we do all for justice. Yes, we are coming from religious origins. But is it our cause to raise Islam's flag? It is not. Our concern is with the world. Our cause is to intervene in injustices between people. Yes we have an Islamic motivation, but our cause is not Islam, which is in the last analysis an abstract thing. We work to get rid of injustices, [we work] for Ali, Ahmet, Ayse. Otherwise many things go under this big flag [the flag of Islam] and many people don't see this. Many bad things emanate from this. [Interview with Akif June 2017]

The above discussion is quite revealing in understanding the group's position vis-à-vis Islamism. While many group members embrace social justice-oriented, egalitarian and emancipatory interpretations of Islam, and use these interpretations as one motivation for their work on the ground, they oppose political Islam, that is, making Islam into an ideological program. Another member made a similar claim: “...while I see an Islamic emphasis [in our work], there is no consensus. We are careful not to foreground this, not to turn it to a slogan" (Interview with Doğan, June 2017). Thus, the group's dissociation from Islamism while still retaining an attachment to Muslim values is a conscious and principled choice, which undermines ideological binaries taken-for-granted in Turkish politics. 
In an attempt to conceptualize the work of LJP and like-minded oppositional groups, Yenigun (2017: 238) distinguishes between two different strands in Islamism and claims that historically the "language of Islamism harbored both a quest for 'justice' (an ethical aspiration) and a quest for 'power' (a political aspiration) with no need to differentiate between the two." Accordingly, the new "Islamic politics" tries to decouple the ethical and political aspirations within Islamism and foregrounds the ethical quest for justice. Thus, Yenigun sees LJP's worldview as a reformulation of Islamism as "an ethical-political project "that places emphasis on freedom, justice, equality, and speaking up against the perceived 'injustices' even when the political leaders who commit them are pious" (2017: 242). The following remarks from a group member are in line with Yenigun's claims: “Mainstream Islamism has to this day focused on influencing government and hence constructed their political doctrines accordingly. This stance, which prioritizes power, has always a problematic relationship with social justice" (Buyukcoskun 2013a). However, LJP differentiates itself from Islamism by separating its embrace of social justice from the grip of political power and engaging in grassroots work.

We think that the group's practices also display similarities to Bayat's conception of post-Islamism. ${ }^{2}$ Bayat (2013: 8) considers post-Islamism both as a condition and a project. As a social condition, post-Islamism refers to "a political and social condition where, following a phase of experimentation, the appeal, energy, and sources of legitimacy of Islamism are exhausted even among its once-ardent supporters". It is no surprise that a significant number of LJP members are (former) Islamists, who broke ranks with mainstream Islamism in Turkey as the AKP started to fuse mainstream Islamism with state authority and authoritarian, exclusionary practices. As one young group member claims:

\footnotetext{
${ }^{2}$ We encountered only one op-ed piece, in which the word post-Islamism is used to describe the Platform's work.
} 
There is diversity in our membership. I define myself as an Islamist, there are also others among our friends who define themselves as Islamist [...] The people we talk to are those who would understand when we say things like Allah, book. We are talking to conservative people [...] Often we say that we left Islamist circles. But you don't exit when you simply say so, you remain in the same cultural environment. The people you are angry at are the same people (Interview with Doğan June 2017).

As the citation above shows, LJP members do not associate their movement with political Islam and claim that their work is outside of Islamism. It is not a surprise that the LJP was established in 2011, when frustration and disappointment with AKP's policies rose, and some broke ranks with the mainstream Islamist movement in Turkey.

Yet, Bayat also sees post-Islamism as a project and defines it as a "conscious attempt to conceptualize and strategize the rationale and modalities of transcending Islamism in social, political, and intellectual domains" (2013: 8). In a similar fashion, the practices of LJP can be seen as transcending the ideology of Islamism, particularly in the social and intellectual domains. By espousing plurality over singularity, deliberation over ideology, vertical organization over hierarchy, equal participation over discipline, and societal engagement over formal politics, the LJP transcends modalities of mainstream Islamism and espouses a poststructuralist new way of doing-politics.

\section{Critiquing State Islam}

Another critique directed towards the AKP is that the party's actions in government affected the way Islam and Islamic activism are perceived by the Turkish society. As one group member writes:

Islamists, who either found or have the hope to find a position and status in media, in bureaucracy, in associations, or Islamists, who - while avoiding status tied their fate to these Islamists through friend circles, and prioritize their friends' sake to truth and justice, became the distributors of a disastrous corruption. 
Unfortunately, Islamism, which was a call to morals and justice, is turned to a ruthless instrument of tyranny by these carriers and proponents. People, who revolt against oppression and raise the voice of dignity, came to a point where they cannot think of Islam as independent from the corrupt language of the powerful (Kızılkaya, 2014).

Hence, Kızılkaya criticizes the clientelist relationships forged between the AKP government and Islamic businesses, civil society organizations and media. While Islamic businesses, civil society and media were touted as key promoters of Turkey's democratization in the 1990s and early 2000s, during AKP governments these organizations exploited the state for funds, revenues and public bids and were eventually coopted by the AKP, losing their civic, independent qualities (Sarfati 2017). Due to AKP's control of the Diyanet and religious bureaucracy in the past 17 years, the line between political Islam and state Islam is also blurred in Turkey. Kizılkaya claims that Islam in Turkey is now associated with the corrupt practices of the authorities, and this contributed to a more negative perception of religion by the larger public.

AKP's authoritarianism reached unprecedented levels after the failed 15 July coup in 2016. In this period, the AKP declared a state of emergency, closed numerous critical media outlets, jailed Kurdish MPs, and purged academics and civil servants. In this atmosphere of political intimidation, the government brought a constitutional amendment to a referendum to transform Turkey's parliamentary democracy to a presidential regime with weak checks. Before the referendum, an LJP member wrote an op-ed entitled "A blessed" ${ }^{3}$ reminder to the Islamists":

The Islamists who were contaminated by the [political] establishment, broke away from the main purpose of tawhid...They idolized the meaning they

\footnotetext{
${ }^{3}$ The Turkish word hayırll is a play on words, as the root word hayır means both a blessing and no, indicating the vote preference of opposing the constitutional change in the referendum.
} 
attributed to their own identity, and through time without recognizing it became Godless in Izzetbegovic's terms... A large majority of them opined that attaining something through business and retaining it is more important than values and principles. Due to their hate against repressiveness (read: Kemalism), they did not question their own relation to established power. Through time they took the beating of their abuser for granted and saw it as their right to beat [others] like their enemies who beat them or even in a manner more repressive than them. They took their enemies as their teachers. They came to a position to desire a one-man dictatorship that they criticized for years. They forgot that there is room for everyone in this country with their way of life and they stripped this [principle] from their goals. They thought imposing uniformity is jihad (Soylu 2017).

Illustrating the concept of pious dissidence, the author accuses Islamists of straying from the messages of Islam that are based on justice and tolerance and for being coopted by the status and power they accrued through political power. In the context of the latest political crackdowns and centralization of political power, he suggests that Islamists now embrace topdown uniformity, repression and one-man-rule, concepts most Islamists criticized in the 1990s when state institutions were controlled by Kemalists.

\section{Conclusion}

A closer look at the discourses and practices of the LJP can inform us how political actors within the religious community contest the neoliberal governmentality imposed by an Islamist government in an authoritarian setting. Foucault repeatedly asserted that politics is a matter of struggle in which the outcome cannot be forecast, because it is dependent upon the realization and deployment of resources, tactics, and strategies in relation to the contest itself. Contestations, resistances, and social antagonisms shape the rule through a systematic provision of alternatives. In this sense, contestation is related to rule, for it may also serve to destabilize a regime of government and depose it either from without or - through the 
absorption of contradictory, counter discourses into rule - from within (O'Malley, Weir and Shearing, 1997; 510). In the context of contestation, there develops new identity frames reflecting the state of flux that the discourse subjects find themselves in. In these environments, the discourse triggers reflective behaviour for the subject as they situate themselves between their belief systems and the world existence.

While writing about the revival of religious being concomitant with the loss of hegemony of the secular at the levels of state, public sphere, and the governance of the self, Göle (2015: 71) stated that rather than sequential replacement of the secular with the religious, we need to think in terms of confrontations as well as recompositions between the two. The claims made by the LJP above illustrate these recompositions by way of the subjects' deliberation within their allocated spaces under polarization. The subject's decision-making in effect to micro-politics of daily life exists in relation to Islam, whereby Islam is rarely monolithic but mediated and interpreted (Nesbitt-Larking and Kinnvall, 2012).

The members of the LJP engage in meaning and claim making, where they foreground the social justice tenets of Islam, religion's civil qualities, and its potential as a liberatory worldview against worldly injustices. By defining religion in this civil, liberatory, and justiceoriented way they engage in the politics of signification (Benford and Snow 2000: 623) and provide counter-frames against AKP's neoliberal authoritarian Islamism. As such, they critique the monopoly of AKP over religious terminology and the usurpation of such terminology by the latter in order to advance its economic goals. The LJP still performs within a world shaped by Islamic terminology but is able to grapple such terminology back from AKP's hold. This becomes their primary route to distance the pious from the "conduct of conduct" assumed by AKP as a way to retain its political control over the Turkish society. To this extent, we believe, 
LJP can demarcate the boundaries of neoliberal governmentality by exposing its "conduct of conduct" even if it cannot gather sufficient support to turn into a significant electoral force.

\section{References}

Allen, John. Lost Geographies of Power. Oxford: Blackwell, 2003.

Altıntaş, Ali. 2014 "Madencilik Kader Olamaz" In Başucu Yazıları. Emek ve Adalet Platformu. Accessed September 2015. http://www.emekveadalet.org/wpcontent/uploads/bas-ucu-yazilari.pdf

Atasoy, Yildiz. Islam's Marriage With Neo-Liberalism: State Transformation in Turkey. London, New York: Palgrave Macmillan, 2009.

Bayat, Asef. "What is Post-Islamism?" ISIM Review 16: 5. . Post-Islamism: The Changing Faces of Political Islam. Oxford: Oxford University Press, 2013.

Benford, Robert D. and David A. Snow. 2000. "Framing Processes and Social Movements: An

Overview and Assessment." Annual Review of Sociology 26: 611-639.

Brown, Wendy. 2005. "Neoliberalism and the End of Liberal Democracy," in Edgework: Critical Essays on Knowledge and Politics. Princeton, NJ: Princeton University Press.

Buğra, Ayșe and Osman Savaşkan. New Capitalism in Turkey: The Relationship Between Politics, Religion and Business. Cheltenham: Edward Elgar, 2014.

Büyükcoşkun, Mustafa Emin. 2013. "Kaza ve Kadere İman" [Belief in Accident and Fate]. Emek ve Adalet Platformu, 27 January, 2013.

Burchell, Graham. "Liberal Government and the Techniques of the Self." In Foucault and Political Reason: Liberalism, Neo-Liberalism and Rationalities of Government, edited by Andrew Barry, Thomas Osborne and Nicholas Rose, 19-36. Chicago, IL: University of Chicago Press, 1993.

Çalışkan, Koray and Michel Callon. "Economization, Part 1: Shifting Attention From the Economy Towards Processes of Economization." Economy and Society 38, no. 3 (2009): 369-398.

Çakır, Ruşen. Emek ve Adalet Paltformu'ndan Mustafa Emin Büyükcoşkun ve Osman Yıldız ile söyleşi [Interview with Mustafa Emin Büyükcoşkun and Osman Yıldız from the Labor and Justice Platform] Medyascopetv, 16 June 2016. Available at http://medyascope.tv/2016/06/16/emek-ve-adalet-platformundan-mustafa-eminbuyukcoskun-ve-osman-yildiz-ile-soylesi/

Campbell, Elaine. 2010. "The Emotional Life of Governmental Power", Foucault Studies 9 (September): 35-53.

Campbell, Timothy and Adam Sitze, eds. Biopolitics. A Reader. Durham, NC, London: Duke University Press, 2013.

Chandler, David. 2013. "Resilience and the Autotelic Subject: Toward a Critique of the Societalization of Security", International Political Sociology 7: 210-226.

.2012. "Resilience and human security: The post-interventionist paradigm." Security Dialogue 43, no.3: 213-229. 
"Dindar aydınlar: Eskiden mazlum olmak zalimin yanında olmamızı gerktirmez." 2013. T24 Băğmsiz Internet Gazetesi, June 14.

"Erdoğan'in en zor ziyareti." [Erdogan's most difficult visit] Sabah, 19 May 2015. Available: https://www.sabah.com.tr/gundem/2010/05/19/erdogan_patlamanin_yasandigi_maden_ocag inda

Emek ve Adalet Platformu. 2011. "Emek ve Adalet Platformu İlkeleri." [Principles of Labor and Justice Platform] Accessed September 2015 http://www.emekveadalet.org/bizkimiz/ .2014. "Emek ve Adalet Platformu Ilekeleri." [Principles of Labor and Justice

Platform]. Accessed September 2015. http://www.emekveadalet.org/duyurular/emek-veadalet-platformu-ilkeleri-2/

Foucault, Michel. The Birth of Biopolitics: Lectures at the Collège de France 1978-1979, ed. Michel Sennelart, translated by Graham Burchell. New York: Picador, 2004.

Gauthier, François and Tuomas Marikainen. Religion in consumer society: brands, consumers and markets. Routledge, 2016.

Göle, Nilüfer. Islam and Secularity: The Future of Europe's Public Sphere. Durham, NC, London: Duke University Press, 2015.

Gordon, Colin. "Governmental Rationality: An Introduction." In The Foucault Effect Studies in Governmentality, edited by Graham Burchell, Colin Gordon, and Peter Miller, 1-52. Chicago, IL: University of Chicago Press, 1991.

Hart, Gillian. "Geography \& Development: Critical Ethnographies." Progress in Human Geography 28, no. 1 (2004): 91-100

Joseph, Jonathan. 2013. "Resilience as embedded neoliberalism: a governmentality approach." Resilience. International Policies, Practices and Discourses 1, no.1: 38-52.

Koca, Bayram. "Türkiye'de İslam ve Sosyalizm İlişkisi Bağlamında Emek ve Adalet Platformu ve Antikapitalist Müslümanlar.” In Türkiye'de İslam ve Sol, 287-336, İstanbul: Vivo Yayin Evi 2014.

Korkut, Umut and Eslen-Ziya, Hande. Politics and Gender Identity in Turkey: Centralised Islam for Socio-Economic Control. Routledge, 2017.

Kızılkaya, Sinan. "Kişisel Bir Not: İslamcılık ve Kürtçülük" Emek ve Adalet Platformu, 1 November, 2014.

Larner, Wendy. "Guest Editorial.” Environment and Planning D: Society and Space 21 (2003): $509-512$.

Marje 62. Bölüm - Emek ve Adalet Platformu, IMCTV, 29 June 2013. Available at https://www.youtube.com/watch? $\mathrm{v}=$ BeTBSaoO-D0. Accessed at May 2017.

Merlingen, Michael. 2008. 'Monster Studies.' International Political Sociology 3(2): 272-274.

Nesbitt-Larking, Paul and Catarina Kinnvall. "The Discursive Frames of Political Psychology." Political Psychology 33, no. 1 (2012): 45-59.

Oksala, Johanna. "Feminism and Neoliberal Governmentality." Foucault Studies 16: 32-53.

O'Malley, Pat, Lorna Weir and Clifford Shearing. "Governmentality, Criticism, Politics." Economy and Society 26, no.4 (1997): 501-517.

Read, Jason. 2009. "A Genealogy of Homo-Economicus: Neoliberalism and the Production of Subjectivity." Foucault Studies 6 (February): 25-36.

Sarfati, Yusuf. "How Turkey's slide to authoritarianism defies modernization theory" Turkish Studies 18, no.3 (2018): 395-415. 
Soylu, Bedri. "İslamcılar İçin \#HAYIRlı Bir Hatırlatma" [A blessed reminder for Islamists], Emek ve Adalet Platformu, 13 February 2017.

Tie, Warwick. 2004. "The Psychic Life of Governmentality," Culture, Theory and Critique 45(2): 161-176.

Tuğal, Cihan "Focus or Acquiesce? Religion and Political Process in Turkey's and Egypt's Neoliberalizations." Development and Change 43, no. 1 (2012b): 23-51.

Van Dijk, Teun A. 1997. "What is political discourse analysis." Belgian journal of linguistics 11, no. 1: 11-52.

Vrasti, Wanda. 2013. "Universal but not truly 'global': governmentality, economic liberalism, and the international." Review of International Studies 39: 49-69.

Wodak, Ruth. "Critical Discourse Analysis." In The Routledge companion to English studies, edited by Leung, Constant, and Brian V. Street, 302-316. London: Routledge, 2014. 